\title{
Cue-Titles, Abbreviations, and Symbols
}

Armstrong Letters of Robert Browning to Miss Isa Blagden, arr. for publication by A. Joseph Armstrong, Waco, Texas, 1923.

Baylor Baylor University, Waco, Texas.

BM British Museum.

BPL Boston Public Library.

Britannica The Encyclopaedia Britannica, 11th ed., 1910-11.

Curle Robert Browning and Julia Wedgwood, A Broken Friendship as Revealed by Their Letters, ed. Richard Curle, New York, 1937.

$D A B$

Dictionary of American Biography.

$D N B$

Dictionary of National Biography.

DeVane W. C. DeVane, A Browning Handbook, New York, 1935.

D \& K New Letters of Robert Browning, ed. W. C. DeVane and K. L. Knickerbocker, New Haven, 1950.

EBB Mrs. Browning.

G\&M W. H. Griffin and H. C. Minchin, The Life of Robert Browning, New York, 1910.

Hood Letters of Robert Browning Collected by Thomas J. Wise, ed. T. L. Hood, London, 1933.

Huxley Elizabeth Barrett Browning: Letters to Her Sister, 1846-1859, ed. Leonard Huxley, London, 1929.

Intimate Intimate Glimpses from Browning's Letter File, Glimpses assembled by A. Joseph Armstrong, Waco, Texas, 1934.

James Henry James, William Wetmore Story and His Friends, Boston, 1903.

$$
\text { [xvii] }
$$


xviii

Kenyon

Marks

MS

NED

NYPL

Orr

PMLA

Ray

RB-EBB

Sotheby

The Letters of Elizabeth Barrett Browning, ed. F. G. Kenyon, New York, 1897.

Jeannette Marks, The Family of the Barrett, New York, 1938.

Manuscript, generally unpublished.

New English Dictionary.

New York Public Library, Berg Collection.

Mrs. Sutherland Orr, Life and Letters of Robert Browning, rev. F. G. Kenyon, Boston, 1908.

Publications of the Modern Language Association. The Letters and Private Papers of William Makepeace Thackeray, ed. G. N. Ray, Cambridge, Mass., 1946.

Letters of Robert Browning and Elizabeth Barrett Barrett, 1845-1846, New York, 1899.

The Browning Collections. Catalogue of Oil Paintings, Drawings \& Prints; Autograph Letters and Manuscripts; Books . . . the Property of R.W. Barrett Browning, Esq., London, 1913.

Thieme-Becker Ulrich Thieme and Felix Becker, Allgemeines Lexikon der bildenden Künstler von der Antike bis zur Gegenwart, Leipzig, 1907-.

TpS Typescript. TpS in BM refers to British Museum ADD 42229-42231, the typescript prepared by Sir Frederic Kenyon for his edition of Mrs. Browning's letters and deposited by him in the British Museum.

$* * *$ Triple asterisks indicate the beginning or end of a letter which exists only in part.

[ ]

Brackets indicate material inserted by the editor. Ellipses indicate omissions from quoted material in the notes, but not from the actual text of the letters.

$<>$

Elongated brackets indicate an irregularity in the manuscript the nature of which is indicated in the notes.

Arabic numerals refer to the present volume. Thus, 86 refers to the letter $86 ; 86.2$ refers to letter 86 , note 2 . Text 86.2 refers not to the note but to the text of the letter at that point. 